\title{
Specific Performance in the DRaft Common Frame of REFERENCE
}

\author{
Hayk Kupelyants
}

\begin{abstract}
The paper undertakes a policy analysis of the remedy of specific performance. It compares the approach of the Draft Common Frame of Reference with the domestic legal systems of selected common law and civil law countries of the European Union with respect to specific performance. The paper then turns to two dilemmas facing any policy judgment about the availability of the specific performance showing no insurmountable policy argument against the remedy. Afterwards, the remedy of specific performance is placed within the framework of legal certainty. In concluding the paper, a case is be made for the general availability of specific performance as fostering legal certainty within the European legal space.
\end{abstract}

\section{A. INTRODUCTION}

Contract law in Europe has undergone the process of Europeanisation. ${ }^{1}$ One example of such Europeanisation is the Draft Common Frame of Reference ('DCFR') published in 2009, which contains the Principles, Definitions and Model Rules of European Private Law. The Expert Group on European Contract Law, mandated by the European Commission, has recently published its report. ${ }^{2}$ However, analysis of the latter will be omitted as it is focused on the narrow subject of sales of goods and lacks detailed discussion of remedies.

The destiny of the DCFR is not yet clear. There are several possible options to implement it: a non-binding instrument, a European directive, a regulation or even a European civil code. ${ }^{3}$ The European Parliament supports the adoption of an optional instrument by means of a Regulation

\footnotetext{
${ }^{1}$ On which see Reinhard Zimmermann, 'Comparative Law and the Europeanization of Private Law' in Mathias Reimann and Reinhard Zimmermann (eds), The Oxford Handbook of Comparative Law (OUP 2006) 539.

${ }^{2}$ A European Contract Law for Consumers and Businesses: Publication of the Results of the Feasibility Study carried out by the Expert Group on European Contract Law for Stakeholders' and Legal Practitioners' Feedback $<$ http://ec.europa.eu/justice/contract/files/feasibility-study_en.pdf $>$ accessed 15 April 2012.

${ }^{3}$ Green Paper from the Commission on Policy Options for Progress towards a European Contract Law for Consumers and Businesses, Brussels $(2010)<\mathrm{http}$ ://eurlex.europa.eu/LexUriServ/LexUriServ.do?uri=COM:2010:0348:FIN:en:PDF $\geq$ accessed 15 April 2012.
} 
encompassing the contract law rules (points 4, 5, 24 of the 8 June 2011 Resolution). ${ }^{4}$

Under the DCFR the creditor can generally avail himself of the remedy of specific performance, subject to certain exceptions. However, not all countries in the European Union are enthusiastic about the remedy of specific performance. Despite the overall tendency of convergence of the diverging legal systems, ${ }^{5}$ a rather small, but quite important minority of States representing the common law world grant the specific performance only in exceptional cases, whereas civil law countries are in general more inclined to allow such a remedy.

The purpose of this paper is to undertake a policy analysis concerning whether it is advisable to adopt the DCFR's favourable position on specific performance, particularly in light of the report of the House of Lords concluding against the harmonization of the general law of contract - including the adoption of specific performance as a primary remedy. ${ }^{6}$ Chapter B of the dissertation will compare the approach of the DCFR with the domestic legal systems of selected common law and civil law countries of the European Union with respect to specific performance. Chapter $\mathrm{C}$ will turn to two dilemmas facing any policy judgment about the availability of the specific performance. Chapter D will be devoted to the concept of legal certainty. In concluding the dissertation, a case will be made for the general availability of specific performance as fostering legal certainty within the European legal space.

\section{B. Comparative ANAlysis}

This Chapter will have the initial purpose of providing a brief overview of the remedy of specific performance in the DCFR and three municipal legal systems, namely England and Wales, France and Germany. In

\footnotetext{
${ }^{4}$ European Parliament Resolution of 8 June 2011 on Policy Options for Progress towards a European Contract Law for Consumers and Businesses (2011/2013(INI)) $<$ http://www.europarl.europa.eu/sides/getDoc.do?type=TA\&language=EN\&reference $=$ P7-TA-2011-0262> accessed 15 April 2012).

${ }^{5}$ René David and Camille Jauffret-Spinozi, Les grands systèmes de droit contemporains (11 ${ }^{\text {th }}$ edn, Dalloz 2001) 8.

${ }^{6}$ House of Lords, European Union Committee, European Contract Law: The Draft Common Frame of

Reference, $<$ http://www.publications.parliament.uk/pa/ld200809/ldselect/ldeucom/95/ 95.pdf $\geq$, accessed 15 April 2012, 19.
} 
addition, the use of the specific performance in the transnational context will be analysed.

\section{DCFR}

The DCFR is not a mere reproduction of a particular national legal system. It is an instrument which tends to find acceptable solutions for all legal systems. Despite that, the remedy of specific performance is generally granted to the creditor, something that a civil law jurist would likely to be pleased to find. The DCFR recognises the specific performance of both monetary obligations, including secondary obligations, such as the payment of interest $^{7}$ (III. - 3:301), and nonmonetary obligations (III. - 3:302).

The right to claim specific performance for monetary obligations is not available in cases in which the creditor has not yet performed the reciprocal obligation for which payment will be due and it is clear that the debtor in the monetary obligation will be unwilling to receive performance (III. - 3:301(2)), provided that one of the following conditions is met:

(a) the creditor could have made a reasonable substitute transaction without significant effort or expenses; or

(b) performance would be unreasonable in the circumstances.

For this exception the drafters of the DCFR provide one example: when the debtor indicated to the creditor his unwillingness to receive the specific performance before the execution has started. ${ }^{8}$

As mentioned above, the specific performance for non-monetary obligations, including remedying free of charge of a performance which is not in conformity with the terms regulating the obligation, is in principle permitted (III - 3:302) if requested in time (III. - 3:302(4)).

The drafters of the DCFR decided to provide for exceptions to the specific performance. This, however, does not affect the award of damages (III - 3:303) as the latter question falls under DCFR III. - 3:104. The remedy of specific performance is refused in the following three

\footnotetext{
${ }^{7}$ Christian von Bar and Eric Clive (eds), Principles, Definitions and Model Rules of European Private Law, Draft Common Frame of Reference (DCFR), Full Edition (Sellier 2010) Vol. 1, 825.

${ }^{8}$ ibid 825-826.
} 
cases:

1. Unlawfulness or impossibility of the performance. The commentary explains that temporary impossibility does not permanently exclude the right to claim specific performance; ${ }^{9}$

2. Performance would be unreasonably burdensome or expensive; ${ }^{10}$ or

3. Personal character of the performance.

This third exception derives from the desire to protect human rights and freedoms of the debtor. ${ }^{11}$ It can only be relied upon when enforcement would be unreasonable on the facts of the case. ${ }^{12}$ This requirement seems to have been construed narrowly by the drafters of the DCFR. Thus, contracts of employment are said to be generally enforceable provided that the obligation is not 'of a highly personal nature'. ${ }^{13}$ The Commentary to the Principles of European Contract Law ('PECL') states that the said exception does not cover negative obligations, namely when a person is forbidden from doing something. However, if as a result of such an injunction a person would in fact be forced to execute a positive act, the exception would be triggered. ${ }^{14}$

Though not mentioned in the text of the DCFR, an order of specific performance would also be refused, when it is not reasonably clear what the debtor is required to do in order to comply with the order. ${ }^{15}$

Aside from these exceptions, the seeming primacy of the specific performance is also undermined by the duty of the creditor to mitigate the

\footnotetext{
${ }^{9}$ ibid 830 .

${ }^{10}$ As explained by the drafters of the DCFR: 'Burdensome does not mean financially burdensome. It is wider than that. It could cover something which involved a disproportionate effort or even something which was liable to cause great distress, vexation or inconvenience' - ibid 831.

11 ibid 832.

${ }^{12}$ Compare to art. 9:102(2)(b) of the PECL which bluntly fenced all contracts for provision of service or work of personal character off the scope of the remedy of specific performance.

${ }^{13}$ von Bar and Clive, Principles, Definitions and Model Rules of European Private Law, Draft Common Frame of Reference (DCFR) (n 7) 831.

${ }^{14}$ Ole Lando and Hugh Beale (eds), Principles of European Contract Law: Parts I and II (Martinus Nijhoff 2000) 397-398.

${ }^{15}$ von Bar and Clive Principles, Definitions and Model Rules of European Private Law, Draft Common Frame of Reference (DCFR) (n 7) 833. CfCo-operative Insurance Society v Argyll Stores [1998] AC 113-14.
} 
loss, particularly regarding fungible goods. Thus, the fact of insisting unreasonably on specific performance in circumstances where the creditor could have made a reasonable substitute transaction without significant effort or expense would preclude the creditor from claiming the increased losses (III - 3:302(5)).

The DCFR arguably gives full effect to parties' agreement on remedies due to its recognition of the principle of party autonomy (DCFR II - 1:102). Party autonomy is, however, moderated by the prohibition to impose unfair contract terms, by the principles of good faith and fair dealing (III - 3:105) and arguably ${ }^{16}$ by the impossibility of changing the procedure and enforcement of obligations by mutual consent (DCFR I $1: 101(2)(h))$.

\section{English Law}

Unlike civil law countries, in common law countries remedies precede and do not necessarily follow the content of rights. ${ }^{17}$ This partially explains the situation whereby specific performance is not the usual and natural consequence of a contractual commitment under English law. ${ }^{18}$ This limited availability of specific performance is also explained by the fact that non-compliance with a judicial order of specific performance would result in contempt of court. The sanction of the contempt of court is quite harsh so that the remedy should only be awarded with caution. ${ }^{19}$

It is a well-established rule in English law that the default remedy for the breach of contract is the award of damages, except for cases when damages are not an adequate remedy. G. Jones qualifies 'the formula of the adequacy of damages as a chameleon one'. ${ }^{20}$ Several cases of

\footnotetext{
${ }^{16}$ Martin Schmidt-Kessel, 'The Right to Specific Performance under the DCFR', in Gerhard Wagner (ed), The Common Frame of Reference: $A$ View from Law and Economics (Sellier 2009) 74.

17 Rene David and Camille Jauffret-Spinozi, Les grands systèmes de droit contemporains (n 5) 262; Lucinda Miller, 'Specific Performance in the Common law and Civil law: Some Lessons for Harmonisation', in Paula Giliker (ed.), Reexamining Contract and Unjust Enrichment: Anglo-Canadian Perspectives (Martinus Nijhoff 2007) 288-289.

18 Daniel Friedmann, 'Rights and Remedies', in Nili Cohen and Ewan McKendrick (eds), Comparative Remedies for Breach of Contract (OUP 2005) 4.

${ }^{19}$ Gareth Jones and William Goodhart, Specific Performance $\left(2^{\text {nd }}\right.$ edn, Butterworths 1996) 6.

${ }^{20}$ Gareth Jones, 'Specific Performance: A Lessee's Covenant to Keep Open a Retail
} 
inadequacy of damages include: 1) when the creditor will be forced out of business, unless he obtains specific performance, ${ }^{21} 2$ ) when goods are unique; ${ }^{22}$ 3) when the performance is due under a long-term supply contract; $^{23} 4$ ) when the breach of duty has an ongoing character; ${ }^{24}{ }_{5}$ ) (arguably) in case of insolvency of the debtor. ${ }^{25}$

A. Farnsworth argues that the test of adequacy of damages has lost its dominant importance; nowadays, common law courts compare remedies in terms of their effectiveness in granting protection to the injured party. ${ }^{26}$ The trend towards greater availability of specific performance is also evidenced by the process of removing some bars to specific performance (e.g. - the requirement of mutuality). ${ }^{27}$

However, this liberal tendency seems to have been stopped by the case of Co-Operative $v$ Argyll in which Lord Hoffman stated that the remedy of specific performance is 'an exceptional remedy' and limited the availability of specific performance of contracts for pursuing activities. ${ }^{28}$ This case was criticised on the ground that the specific performance needs to be refused if it causes undue hardship rather than because it falls into a pre-determined category of contracts. ${ }^{29}$

Notwithstanding the traditional reluctance to grant specific performance, English law echoes certain provisions of the DCFR. Firstly, English law recognises the non-discretionary character of an action for an

Store' (1997) 56 Cambridge L. J. 488-490.

${ }^{21}$ Sky Petroleum Ltd. v V.I.P. Petroleum Ltd. [1974] 1 W.L.R. 576. The risk of forcing the party out of business distinguishes this case from the case of Société des Industries Métallurgiques v The Bronx Engineering Co Ltd [1975] 1 Lloyd's Rep. 465 , in which the claim of specific performance was rejected.

${ }^{22}$ Falcke v Grey (1859) 4 Drew 651.

${ }^{23}$ Robert Sharpe, Injunctions and Specific Performance (Canada Law Book Co 1983) 682.

${ }^{24}$ S.A. Smith, 'Substitutionary Damages', in Charles Rickett, Justifying Private Law Damages (Hart Publishing 2008) 106.

${ }^{25}$ Ralph Cunnington, 'The Inadequacy of Damages as a Remedy for Breach of Contract', in Charles Rickett, Justifying Private Law Damages (n 24) 118-119.

${ }^{26}$ Allan Farnsworth, 'Comparative Contract Law', in Mathias Reimann and Reinhard Zimmermann (eds), The Oxford Handbook of Comparative Law (OUP 2006) 932.

${ }^{27}$ Allan Farnsworth, Contracts $\left(4^{\text {th }}\right.$ edn, Aspen Publishers 2011) 742.

${ }^{28}$ Bénédicte Fauvarque-Cosson, 'Regards Comparatistes sur l'Exécution Forcée en Nature' (2006) 1 Revue des contrats 259.

${ }^{29}$ I.C.F. Spry, The Principles of Equitable Remedies: Specific Performance, Injunctions, Rectification and Equitable Damages $\left(6^{\text {th }}\right.$ edn, Sweet \& Maxwell 2001) 669 - 671. For contrary evidence see Shiloh Spinners Ltd v Harding [1973] A.C. 691. 
agreed sum. ${ }^{30}$ However, unlike the DCFR, under English law the payment extended in time (periodical payment of annuities) is subject to discretionary powers of the court. ${ }^{31}$ The contract to lend money is not qualified as a contract to pay a specified sum of money; therefore, an order of specific performance would not be granted, provided damages are an adequate remedy. ${ }^{32}$ In addition, s. 49 of the Sale of Goods Act (1979) does not recognize the right of the seller to sue for the price of the title that has not passed to the buyer. ${ }^{33}$

Following the case of White and Carter (Councils) v MacGregor ${ }^{34}$ the debtor may continue performance and require the payment provided that the performance may be carried out without co-operation by the other party, the performing party has a legitimate interest in performance and that such continuation should not breach the duty to mitigate losses. ${ }^{35}$ Subsequent cases emphasise the ability of the creditor to stop the debtor from going ahead with the performance of the contract. ${ }^{36}$

English courts would not order performance when the costs of performing an obligation would be disproportionate to the benefits to be received by the debtor. ${ }^{37}$ In Co-operative $v$ Argyll, the House of Lords rejected the obligation to operate an unprofitable business. However, the strict approach of this case should not be accepted wholesale. In Rainbow Estates Ltd $v$ Tokenhold $L t d{ }^{38}$ the court rejected the application of limiting factors (e.g. - constant judicial supervision or the precision as to the content of duties that need to be performed to satisfy the court's order of specific performance) to the facts of that case considering that those

\footnotetext{
${ }^{30}$ Edwin Peel, Treitel on the Law of Contract $\left(12^{\text {th }}\right.$ edn, Sweet \& Maxwell 2007) 1092-1100. The House of Lords in White and Carter (Councils) Ltd v McGregor ([1962] AC 413) where the issue at stake was the claim of debt rejected use of discretionary power and granted an order of specific performance.

${ }^{31}$ Beswick v Beswick [1968] AC 58 (HL).

${ }^{32}$ South African Territories, Limited v Wallington [1897] 1 Q.B. 692.

${ }^{33}$ Criticized as unreasonable by P.S. Atiyah, John Adams and Hector MacQueen (eds), Atiyah's Sale of Goods (12 ${ }^{\text {th }}$ edn, Longman n 2010) 482-484).

${ }^{34}$ White and Carter (Councils) v MacGregor [1962] AC 413. For the same principle in U.S. judicial practice see Rockingham County v Luten Bridge, 35 F. 2d 301 (4th Cir 1929) 307.

${ }^{35}$ Guenter Treitel, Remedies for Breach of Contract (OUP 1988) 127

${ }^{36}$ Ewan McKendrick, Contract Law: Text, Cases and Materials ( $3^{\text {rd }}$ edn, OUP 2008) 825-828.

${ }^{37}$ Tito v Waddel (No 2) [1977] Ch. 106, 326.

${ }^{38}$ [1999] Ch. 64 (Ch D).
} 
factors are not absolute values but rather matters of degree. ${ }^{39}$

The next exception is the prohibition to impose specific performance of personal character, which would render the performance unreasonable. On several occasions, English courts refused to compel the party to carry out services of personal character unless it was reasonable to do so. ${ }^{40}$ The discretionary judicial analysis of the reasonableness takes into account a number of factors such as the hardship suffered by both parties where the personal service is not performed and the degree of judicial superintendence. ${ }^{41}$ English courts would be more inclined to grant injunctions rather than orders for specific performance, ${ }^{42}$ not least because such orders infringe less on debtor's freedom and are supervised with more ease. ${ }^{43}$

So far, the approaches adopted by the DCFR and English law intersect frequently. However, quite importantly, a greater number of exceptions to the specific performance are available under English law in contrast to the DCFR. Thus, English courts will consider additional factors to reject a claim for specific performance: the necessity of constant judicial supervision, set-off, ${ }^{44}$ lack of clean hands, ${ }^{45}$ public policy, ${ }^{46}$ lack of equal footing of parties as to the value of goods sold ${ }^{47}$ and the impossibility to perform the contract in its entirety. ${ }^{48}$ Specific

\footnotetext{
${ }^{39}$ Peter Luxton, 'Goodbye Hill v Barclay: specific performance of a tenant's repairing covenant - Rainbow Estates Ltd v Tokenhold Ltd' (1988) JBL 564, 566.

${ }^{40}$ Andrew Burrows, Remedies for Torts and Breach of Contract (Oxford 2004) 530.

${ }^{41}$ Gareth Jones, 'Specific Performance of a Contract of Services?' (1987) 46 Cambridge L. J. 21, 23.

${ }^{42}$ Hugh Beale (ed), Chitty on Contracts ( $28^{\text {th }}$ edn, Sweet \& Maxwell 2004), para. $27-$ 059 , cited in S. J. Whittaker, 'Un droit à la prestation plûtot qu'un droit à l'exécution? Réflexions sur l'exécution en nature et réparation en droit anglais' (2005) Revue des contrats 49, 53. Compare Co-operative Insurance Society v Argyll Stores [1998] AC 1 to the case of Walgreen $v$ Sara Creek Property, 966 F. 2d 273 (7th Cir 1993), in which the negative injunction was granted.

${ }^{43}$ Robert Shape, Injunctions and Specific Performance (n 23) 547-548.

${ }^{44}$ David Hayton, Charles Mitchell, The Law of Trusts and Equitable Remedies (12th edn, Sweet \& Maxwell 2005) 908.

${ }^{45}$ Walters v Morgan (1861) 45 E.R. 1056.

${ }^{46}$ Jill Martin (ed), Hanbury \& Martin on Modern Equity $\left(17^{\text {th }}\right.$ edn, Sweet \& Maxwell $2005)$ 754-755.

${ }^{47}$ Falcke v Grey (1859) 4 Drew 651.

${ }^{48}$ Performance will not be impossible if the debtor can force a company, in which he has a majority of shares, to perform the contract (Elliott v Pierson [1948] 1 All ER
} 
performance will also be refused when the obligations sought to be enforced require performance of activities abroad or the property in question is situated abroad. ${ }^{49}$ Finally, more general doctrines can be used to bar the remedy of specific performance (such as estoppel). ${ }^{50}$

Even when applying the same exception the scope of English exceptions is more expansive. Thus, the exception of 'burdensome performance' in the text of the DCFR seems to be confined only to the person of the creditor, whereas English law takes into account the burden which could be imposed on the wife of the creditor. ${ }^{51}$

As seen, specific performance is not entirely excluded from English law: a set of circumstances may in certain cases justify the order of specific performance. This position is at odds with the rule in English conflict of laws, which plainly refuses recognition of foreign judgments other than for a 'debt, or definite sum of money', thus excluding specific performance of obligations provided for by foreign judgments. ${ }^{52}$

With regard to the freedom of parties to stipulate the remedy before the arising of the dispute, the position of English law is not entirely clear. ${ }^{53}$ While it seems that courts would be reluctant to enforce partyagreed specific performance clauses, such reluctance is justified by invocation of paternalistic concerns ${ }^{54}$ and by the argument that parties cannot oust the power of courts through their private agreement. ${ }^{55}$ However, there has been made a convincing case for the respect of

939). For limitations to the scope of this exception see Jones and Goodhart, Specific Performance (n 19) 57-61.

${ }^{49}$ I.C.F. Spry, The Principles of Equitable Remedies: Specific Performance, Injunctions, Rectification and Equitable Damages (n 29) 78.

${ }^{50}$ Jones and Goodhart, Specific Performance (n 19) 26.

${ }^{51}$ Wroth v Tyler [1974] Ch. 30.

${ }^{52}$ Lawrence Collins et al. (eds), Dicey, Morris, Collins: The Conflict of Laws $\left(13^{\text {th }}\right.$ edn, Sweet \& Maxwell 2006) 1st vol. 576, though such a judgment can have res judicata effect.

${ }_{53}$ Burrows, Remedies for Torts and Breach of Contract (n 40) 505. Quadrant Visual Communications Ltd. v Hutchison Telephone (UK) [1993] BCLC 442 did not give effect to contractually-stipulated remedies, however Miller $(\mathrm{n} 17,294)$ argues that the reason for that may be that plaintiff acted in a dishonest way in that case.

${ }^{54}$ Anthony Ogus, 'English Report on Remedies', in Donald Harris and Denis Tallon (eds), Contract Law Today: Anglo-French Comparisons (OUP 1989) 247.

${ }_{55}$ Anthony Kronman, 'Specific Performance' (1978) 45 U. Chi. L. Rev. 351, 371. 
freedom of parties to agree on remedial terms. ${ }^{56}$ It is unclear why parties cannot contract on their private matters provided there is no public interest involved in the case (e.g. - specific performance tantamount to slavery or protection of weak parties). Moreover, such an approach would be efficient from the viewpoint of the Coase theorem. ${ }^{57}$

\section{French Law}

French law recognises the duty of the debtor mis en demeure ('debtor required by the creditor to comply with his duties') to specifically perform his contractual obligations. ${ }^{58}$ The availability of specific performance depends on the character of the obligation that the debtor promised to perform. For the purposes of granting an order of specific performance, distinction is made between the obligations to 'give' and to 'do' or 'abstain'. The obligations to 'give', including obligations to pay and to deliver goods, ${ }^{59}$ are perfectly susceptible of performance. If the goods are fungible and the debtor should first individualise them, the obligation to give is transformed into an obligation to 'do' which is subject to a special regime (see below). ${ }^{60}$

In cases of obligations to 'do' or 'abstain', the principle is reversed: the specific performance is prohibited (Article 1142 of the French Civil Code, qualified by Articles 1143 and 1144) due to concerns relating to the constraint exercised on human personality and the practical inefficiency of any work exercised under constraint. ${ }^{61}$ The French caselaw ${ }^{62}$ reversed this principle by recognising specific performance for obligations to 'do' or 'abstain' except in strictly personal contracts. ${ }^{63}$ This

\footnotetext{
${ }^{56}$ Solène Rowan, For the Recognition of Remedial Terms Agreed Inter Partes' (2010) $126 L Q R 448$.

${ }^{57}$ On which see R Coase, 'The Problem of Social Cost' (1960) 3 J. L. \& Econ. 1.

${ }^{58}$ François Terré, Philippe Simler and Yves Lequette, Droit civil: les obligations (Dalloz 2005) 1059.

${ }^{59}$ Civ. 20.1.1953, D. 1953.222, JCP 1953.II.7677.

${ }^{60}$ Boris Starck, Henri Roland and Laurent Boyer, Droit civil: les obligations $\left(6^{\text {th }} \mathrm{edn}\right.$, Litec 1998) 565.

${ }^{61}$ ibid 566.

${ }^{62}$ Cass. Civ. 20.1.1953, D. 1953.222, JCP 1953.II.7677, cited in Barry Nicholas, The French Law of Contract ( $2^{\text {nd }}$ edn, OUP 1992) 219.

${ }^{63}$ Geneviève Viney, 'Exécution de l'obligation, faculté de remplacement et réparation en nature en droit français', in Marcel Fontaine and Geneviève Viney (dir.), Les sanctions de l'inexécution des obligations contractuelles: études de droit comparé
} 
change of the principle is embraced by Avant-projet Catala (Art. 1154) and the Draft of the Ministry of Justice (Art. $110 \& 162$ ) purporting to amend the French Civil Code. ${ }^{64}$ The adoption of latter amendments would strip French courts of the discretionary power they are said to enjoy to control the proportionality of a remedy of specific performance. $^{65}$

One of the particularities of the French law is that the specific performance is secured by the imposition of a mechanism of coercion called astreinte. ${ }^{66}$ Astreinte consists in imposing a considerably high judicial fine, "not depending upon damages, ${ }^{, 67}$ on the debtor who refuses to execute specifically his obligations under the contract. The amount of astreinte is in direct proportion to the time during which the debtor was reluctant to perform his contractual obligations. ${ }^{68}$

The astreinte is extremely efficient. While orders of specific performance can face irresistible obstacles to enforcement, astreinte provides a very strong incentive for complying with contractual obligations. Nevertheless, the mechanism of astreinte is not devoid of deficiencies. The award of an astreinte does not depend on the damage caused, thus permitting the astreinte to transform itself in a punitive damage in case the debtor is reluctant to perform his obligations for a considerable period of time. This feature of the astreinte can convert the amount of money to be paid due to a breach of contract into a penal rather

(Bruylant 2001) 176-178; Y.M. Laithier, 'Comparative Reflections on the French Law of Remedies for Breach of Contract', in Cohen and McKendrick (eds), Comparative Remedies for Breach of Contract (n 18) 113.

${ }^{64}$ Hugh Beale, Bénédicte Fauvarque-Cosson, Jacobien Rutgers, Denis Tallon and Stefan Vogenauer, Cases, Materials and Text on Contract Law (Hart Publishing 2010) 843-844.

${ }^{65}$ Judith Rochfeld, 'Remarques sur les propositions relatives à l'exécution et à l'inexécution du contrat: la subjectivisation du droit de l'exécution' (2006) 1 Revue des contrats 117; John Gotanda, Damages in Private International Law, (Martinus Nijhoff 2007) 10; Laithier (n 63) 113-114. Nevertheless, there is a recent case law which denies such discretion to French courts: Cas. Com. 3 dec. 1985, B. IV No. 286 , p. 244 cited in Lando and Beale, Principles of European Contract Law: Parts I and II (n 14) 399.

${ }^{66}$ Charles Szladits, 'The Concept of Specific Performance in Civil law' (1955) $4 \mathrm{Am}$. J. Comp. L. 208, 218.

${ }^{67}$ L. 9 juill. 1991, article 34.

${ }^{68}$ The mechanism of astreinte is also provided for by Art 111 (3) of the Code Européen des contrats: Giuseppe Gandolfi, Code Européens des contrats: avantprojet (Giuffrè 2004) 45. 
than compensatory sanction, ${ }^{69}$ which is considered to be non-convenient for the contractual domain. ${ }^{70}$ The severe character of astreinte is, however, mitigated by discretion of the court to reduce the amount of the provisional astreinte, and, in particular, by Art. 36 of L. 9 juill. 1991 which permits to lift the astreinte when non-performance was induced by extraneous causes. $^{71}$

Impossibility of the performance would preclude any order for specific performance. ${ }^{72}$ However, French case law does not recognise an exception for exceptionally burdensome or expensive performances ${ }^{73}$ due to the considerations of the sanctity and immutability of contracts. ${ }^{74}$ Nor is there any proportionality considerations balancing the interest of the creditor in performance with the expenses incurred by the debtor. Thus, in one case the debtor was ordered to demolish and reconstruct a house because of 33 missing centimetres. ${ }^{75}$ This approach will give the debtor a strong bargaining power during the negotiations following a judgment for specific performance which could be used to extract from the debtor more damages that have been suffered. ${ }^{76}$

The proposed reforms to the French civil law, namely Avant-projet Catala and the Draft of the Ministry of Justice, leave the defences available against a claim of specific performance untouched: the economic impossibility of the specific performance (disproportionate character of performance) and the duty to mitigate damages cannot prevent an order of specific performance from being granted. ${ }^{77}$

\footnotetext{
${ }^{69}$ For this reason a U.S. court (Laminoirs-Trefileries-Cableries de Lens SA v Southwire Co. (484 F. Supp. 1063 (ND Ga., 1980)) did not enforce an arbitral award ordering astreinte, on the ground of public policy.

${ }^{70}$ See e.g., Solene Rowan, 'Reflections on the Introduction of Punitive Damages for Breach of Contract' (2010) 30 Oxf. J. Leg. Stud. 495.

${ }^{71}$ Tallon, 'French Report on Remedies', in Harris and Tallon (eds.), Contract Law Today: Anglo-French Comparisons (n 54) 269.

${ }^{72}$ Viney (n 63) 183; Nicholas, The French law of Contract (n 62) 216.

${ }^{73}$ Cass. Civ. 3, 9 déc. 1975, B. III, no. 363, p. 275; Cass. Civ. 1ere, 16 janv. 2007, RDC/TBH 2007. 719, obs. D. Mazeaud.

${ }^{74}$ Laithier (n 63) 104-105.

${ }^{75}$ Fauvarque-Cosson (n 28) 259.

${ }^{76}$ ibid.

${ }^{77}$ Y.M. Laithier, 'The Enforcement of Contractual Obligations: A French Perspective', in John Cartwright, Stefan Vogenauer and Simon Whittaker (eds), Reforming the French Law of Obligations: Comparative Reflections on the Avant-
} 
The effectiveness of party-agreed remedies is not clear in France, ${ }^{78}$ though it is suggested that agreements to restrict the use of specific performance are perfectly enforceable. ${ }^{79}$

\section{German Law}

The starting premise of German law is the availability of a claim for specific performance for a breach of an obligation, including contractual obligations ( $\$ 241(1)$ BGB). Unlike DCFR and English law, German law requires from the creditor to grant the debtor a period of grace (Nachfrist) to keep the contract alive ${ }^{80}$ before other remedies (e.g. - damages, termination) can be requested $\left(\$ \S 281(1), 323\right.$ BGB). ${ }^{81}$ Consequently, the creditor is primarily restricted to specific performance. ${ }^{82}$ However, there are exceptions for certain cases ( $\$ 249(2), 281(2), 283$ and 323(2) BGB) and the period of grace can be substituted by a warning in other cases $(\S \S$ 323(3), 281(3) BGB).

Under German law, the debtor can be released from the duty to perform an obligation specifically in a number of exceptional situations. ${ }^{83}$ First, specific performance is not ordered when performance would be objectively impossible ( $\$ 275(1)$ BGB). The scope of $\$ 275(1)$ BGB covers also illegality of performance. ${ }^{84}$

$\$ 275(2)$ BGB, as a manifestation of the principle of good faith, permits the debtor to avoid specific performance when the performance is grossly disproportionate to the interest in performance of the creditor. ${ }^{85}$

Projet de Reforme du Droit des Obligations et de la Prescription ('The Avant-Projet Catala') (Hart Publishing 2009) 135-137.

${ }^{78}$ Ogus, 'Summary of Discussion of Remedies', in Harris and Tallon (eds), Contract Law Today: Anglo-French comparisons (n 54) 297.

${ }^{79}$ Fauvarque-Cosson (n 28) 259.

${ }^{80}$ B.S. Markesinis, Hannes Unberath and Angus Johnston, The German Law of Contract ( $2^{\text {nd }}$ edn, Hart Publishing 2006) 381.

${ }^{81}$ ibid 400.

${ }^{82}$ Vanessa Mak, Performance-Oriented Remedies in European Sale of Goods Law (Hart Publishing 2009) 92-93.

${ }^{83}$ Treitel, Remedies (n 35) 52-53.

${ }^{84}$ Florian Faust and Volker Wiese, 'Specific Performance - A German Perspective', in Jan Smits, Daniel Haas and Geerte Hesen (eds), Specific Performance in Contract Law: National and Other Perspectives (Hart Publishing 2008) 52.

${ }^{85}$ Compare with French case-law which orders specific performance of an obligation even if the interest of the debtor in performance is slight: Beale, Fauvarque-Cosson, 
However, unlike the situations of objective impossibility $(\$ 275(1)$ BGB), ${ }^{86}$ the court should not be ignorant of the role of the debtor in rendering the performance grossly disproportionate. The doctrine limits $\S 275(2)$ BGB to extreme cases $^{87}$ and it could not be used in cases of 'economical impossibility' when, for example, prices for the goods increase drastically; $\$ 313$ would need to be applied in such a case. ${ }^{88} \mathrm{In}$ addition, the debtor can rely upon $\$ 765$ (a) of the Civil Procedure Code ${ }^{89}$ to discontinue specific performance if severe hardship has emerged after the order of specific performance was rendered.

The debtor is also protected from being forced to execute a personal duty ( $\$ 275(3) \mathrm{BGB})$. When faced with a contract to execute a personal duty, the court should weigh the obstacle to the performance of the debtor against the interest of the creditor in performance. Even if conditions for applying §275(3) BGB are not met, §888(3) of the Civil Procedure Code will exclude the forced enforcement of judgments for non-delegable personal services.

In case of impossibility of performance, other remedies are still available to the creditor (e.g. - damages) ${ }^{90}$ provided the requirements of $\$ 280$ BGB are met. By virtue of $\$ 326(1)$ BGB the creditor would also be exempted from his contractual obligations towards the debtor in case of impossibility subject to an exceptional case when the creditor contributes to the situation of impossibility ( $\$ 326(2)$ BGB).

An overview of civil procedural rules is necessary to elucidate the practical application of the remedy of specific performance in Germany. $\S 888$ of the Civil Procedure Code provides for sanctions in case the debtor does not comply with his duty to specifically perform the contract. Only when the activity required to perform is dependent exclusively on

Rutgers, Tallon, Vogenauer, Cases, Materials and Text on Contract Law (n 64) 856857.

${ }^{86}$ Reinhard Zimmermann, The New German Law of Obligations: Historical and Comparative Perspectives (OUP 2005) 44.

${ }_{87}^{87}$ Markesinis, Unberath and Johnston, The German Law of Contract (n 80) 413.

${ }^{88}$ Zimmermann, The New German Law of Obligations: Historical and Comparative Perspectives (n 86) 45-46.

${ }^{89}$ Cited in Beale et al, Cases, Materials and Text on Contract Law (n 64) 882.

${ }^{90}$ Andreas Heldrich and Gebhard Rehm, 'Modernisation of the German Law of Obligations: Harmonisation of Civil Law and Common Law in the Recent Reform of the German Civil Code', in Cohen and McKendrick (eds), Comparative Remedies for Breach of Contract (n 18) 129. 
the will of creditor and cannot be undertaken by a third party, fines and imprisonment can be ordered against the debtor, subject to the principle of proportionality (in case of imprisonment) and ceiling of 25000 EUR for fines. ${ }^{91}$

$\$ 887$ of the Civil Procedure Code requires the debtor to contract for a substitute performance where the obligation to 'do' can be performed by a third party. It is sometimes argued that the primacy of the specific performance in civil law countries is a myth. ${ }^{92}$ Nevertheless, it would be rash to qualify specific performance as a myth, because $\$ 887$ exception is limited to obligations to 'do'. By contrast, the specific performance of contracts to give can be forced.

Two other actions available to the creditor are an action to forbear the debtor from doing something ( $\$ 890(1)$ of the Civil Procedure Code) and the action to force the debtor to pay the money ( $\$ 803$ of the Civil Procedure Code)..$^{93}$

\section{Transnational Context}

Point 31 of the European Parliament resolution (8 June, 2011) encourages the use of the European optional instrument on contractual obligations within the context of the alternative dispute resolution, allegedly including arbitration. Accordingly, it is necessary to test the position of the DCFR which can form the base for such an optional instrument by reference to the context of international arbitration.

Traditionally, there has been a dichotomy of views about the law applicable to the issue of remedies in arbitration. The common law world used to think about remedies as a procedural issue governed by the lex arbitri.$^{94}$ For instance, s. $48(5)$ of the English Arbitration Act of 1998 grants arbitrators sitting in England, Wales and Northern Ireland the power to order specific performance. The application of the lex arbitri to

\footnotetext{
${ }^{91}$ Markesinis, Unberath and Johnston, The German Law of Contract (n 80) 405.

${ }^{92}$ Henrik Lando and Caspar Rose, 'On The Enforcement Of Specific Performance In Civil Law Countries' (2004) 24 Int'l Rev. L. \& Econ. 473.

${ }_{93}$ Markesinis, Unberath and Johnston, The German Law of Contract (n 80) 403, 405.

${ }^{94}$ See for the discussion D.R. Munoz, 'The Power of Arbitrators to Make Pro Futuro Orders', in Michael Schneider and Joachim Knoll (eds), Performance as a Remedy: Non-Monetary Relief in International Arbitration (New York, 2011) 93. In practice lex arbitri quite often governs the order of specific performance (Robert Gemmel, 'To Order Specific Performance?' (2010) 76 Arbitration 467-473).
} 
the issue of specific performance may lead to a conflict with the substantive law applicable to the dispute which may have a different approach to the availability of specific performance. On the other side, the civil law system treats remedies as a substantive law issue. This view is supported by Art. 12 of the Rome I Regulation ${ }^{95}$ which states that the applicable substantive law will govern the question of remedies, subject to procedural limits of the court, as well as by eminent arbitration scholars. $^{96}$

Nevertheless, it is submitted that international commercial arbitration is not a mere procedural mechanism to solve the dispute between merchants. The choice of international arbitration, according to recent studies, impacts upon the content of substantive law that arbitrators apply. Arbitrators tend to apply legal rules independently from national legal systems, ${ }^{97}$ frequently citing 'general principles of law'. One might here think of the much-debated concept of lex mercatoria. ${ }^{98}$ It was claimed by a sole arbitrator in Texaco/Calasiatic $v$ Libya that specific performance is a general principle of law. ${ }^{99}$ However, the analysis of legal systems above shows considerable discrepancies between legal systems as to whether an order for specific performance should be granted. Nevertheless, it is not necessary for a rule, in our case specific performance, to be a general principle of law to be applied by arbitrators $^{100}$ due to the fact that the rules applicable in transnational context are not mere reproductions of provisions of national legal systems. ${ }^{101}$ Almost all major institutional rules require from arbitrators to

${ }^{95}$ Council Regulation (EC) No 593/2008 of the European Parliament and of the Council of 17 June 2008 on the law applicable to contractual obligations (OJL 177, 4.7.2008).

${ }^{96}$ Gary Born, International Commercial Arbitration (3 ${ }^{\text {rd }}$ ed. 2009), Vol. II, 2150.

${ }^{97} \mathrm{See}$ a PhD project by Joshua Karton, The Culture of International Arbitration and the Evolution of Contract Law, <http://www.law.cam.ac.uk/people/researchstudents/joshua-karton/2114> accessed 15 April 2012.

${ }^{98}$ See, e.g., Berthold Goldman, 'The Applicable Law: General Principles of Law The Lex Mercatoria', in Julian Lew (ed), Contemporary Problems in International Arbitration (Kluwer 1986) 113; Michael Mustill, 'The Lex Mercatoria: The First Twenty-Five Years', (1988) 4 Arbitr. Int'l 108.

99 Award of 19 January 1977, 17 ILM 1 (1978).

${ }^{100}$ For a contrary view see Emmanuel Gaillard, 'Thirty Years of Lex Mercatoria: Towards the Selective Application of Transnational Rules' (1995) 10 ICSID Review 208.

${ }^{101}$ Karton (n 97). 
give effect to the substantive content of parties' agreement. ${ }^{102}$ As a result, one could, according to one author, argue that arbitrators have the inherent power $^{103}$ to order specific performance subject to inherent limitations such as intuitu personae character of the obligation. ${ }^{104}$

\section{Preliminary Conclusions}

The analysis above shows that specific performance is subject to diverging regimes in the legal systems compared. Despite some exceptions which are uncontroversial, such as impossibility, ${ }^{105}$ the argument that legal systems reach the same results on the practical level with regards to the specific performance ${ }^{106}$ appears to be an oversimplification. First, legal systems seem to differ as to the definition of specific performance. The notion of specific performance is broader in French and German laws than under English law. The former encompasses execution of the contract by a third party at the expenses of the creditor (articles 1143-1144 of French Civil Code, §887(1) German Code of Civil Procedure), provided there is a preliminary judicial decision to that effect. ${ }^{107}$ However, it seems that English courts also have the power to substitute the performance of a debtor by ordering execution by a third party. ${ }^{108}$ In addition, the civil law concept of specific performance includes in its scope the negative obligations (prohibitions), which are enforced through negative injunctions, whereas English law does not consider them to be part of specific performance, ${ }^{109}$ where they

\footnotetext{
${ }^{102}$ Michael Schneider, 'Non-Monetary Relief in International Arbitration: Principles and Arbitration Practice', in Michael Schneider and Joachim Knoll (eds),

Performance as a Remedy: Non-monetary Relief in International Arbitration (Juris Publishing 2011) 4-5.

${ }^{103}$ David Munoz, 'The Power of Arbitrators to Make Pro Futuro Orders' in Michael Schneider and Joachim Knoll (eds), Performance as a Remedy: Non-Monetary Relief in International Arbitration (Juris Publishing 2011) 109.

${ }^{104}$ Carole Malinvaud, 'Non-pecuniary Remedies in Investment Treaty and Commercial Arbitration' (2009) 14 ICCA Congress Series 212-213.

105 von Bar and Clive, Principles, Definitions and Model Rules of European Private Law, Draft Common Frame of Reference (DCFR) (n 7) 837.

${ }^{106}$ Konrad Zweigert and Hein Kötz, An Introduction to Comparative Law $\left(3^{\text {rd }} \mathrm{edn}\right.$, Clarendon Press 1998) 484.

${ }^{107}$ Beale et al, Cases, Materials and Text on Contract Law (n 64) 851.

${ }^{108}$ Rule 8 of the Schedule 1 of the RSC Order 45 (Enforcement of Judgments and Orders: General).

${ }^{109}$ Szladits (n 66) 212.
} 
are considered to be a manifestation of the compensation for breach of contract. ${ }^{110}$ The DCFR is silent as to the definition of the specific performance.

English law seems to have more restrictive approach to the specific performance of monetary obligations than other legal systems. ${ }^{111}$ Except for rules for particular contracts ${ }^{112}$ the civil law systems, in contrast to English law (White and Carter v McGregor), ${ }^{13}$ do not permit the creditor to stop the performance which he is not interested in. ${ }^{114}$

Turning to the execution of non-monetary obligations, German and French laws, unlike English law, ${ }^{115}$ require some form of communication to the debtor about the non-execution of his duties.

It is sometimes argued that substitute performance is the primary remedy in civil law countries. ${ }^{116}$ This conclusion is doubtful taking into account that the existence of a cover transaction will not generally force the creditor to opt for it in most legal systems. ${ }^{117}$ In English law existence of a cover transaction would point towards adequacy of damages thus preventing an order for specific performance. The duty to mitigate damages is provided for under the DCFR. Interestingly, under English law the creditor needs to mitigate his damage also in case of a claim for performance of monetary obligations, ${ }^{118}$ whereas under the DCFR he need only do so for performance of non-monetary obligations.

Exceptions to specific performance are not uniformly applied in different legal systems, and their scopes diverge throughout EU Member States. Though substantive provision in civil law countries may entitle the creditor to sue for specific performance, civil procedural rules can have

\footnotetext{
${ }^{110}$ Treitel, Remedies (n 35) 57.

${ }^{111}$ See part B.2 above.

${ }^{112}$ G.J.P. de Vries, 'Do Economic Analysis and Fairness Influence the Right to

Performance in Ways Contrary to One Another?' in Smits, Haas and Hesen (eds),

Specific Performance in Contract Law: National and Other Perspectives (n 84) 331.

113 [1962] AC 413 (HL Sc).

114 Lando and Beale (n 14) 394.

115 Tony Weir, 'Mise en demeure, dommages et intérêts', in Fontaine, Viney (dir.),

Les sanctions de l'inexécution des obligations contractuelles: études de droit comparé (n 63) 966.

116 Lando and Rose (n 92) 20.

${ }^{117}$ Laithier (n 63) 115; von Bar and Clive, Principles, Definitions and Model Rules of European Private Law, Draft Common Frame of Reference (DCFR) (n 7) 841.

${ }^{118}$ Andrew Burrows, 'Legislative Reform of Remedies for Breach of Contract: the English Perspective' (1997) 1 Edin. L. Rev. 155,157.
} 
the effect of restricting the availability of that remedy. ${ }^{119}$ It should be stressed that codification like the DCFR would not be efficacious unless it will be extended to the area of civil procedure, including interim measures. Therefore, the DCFR should provide that the application of procedural rules should not impair the availability of specific performance.

Analysis of arbitration context also supports the need to render the remedy of specific performance generally available.

\section{Two Dilemmas}

Two fundamental dilemmas lie at the roots of the policy discussions on the availability of specific performance. ${ }^{120}$

\section{Freedom of Debtor vs. Pacta Sunt Servanda}

We must first begin by confronting, on the one hand, the freedom of the debtor to execute or to abstain from executing the contract and, on the other hand, the expectations of the creditor ${ }^{121}$ and the principle of pacta sunt servanda. ${ }^{122}$ It is quite often argued that ordering specific performance would hinder the personal freedom of the debtor and his right to change his mind. ${ }^{123}$ By contracting, the debtor does not undertake definitive commitments as the freedom to contract goes along with the freedom to break promises. ${ }^{124}$

However, this argument is flawed. The question of remedies should

\footnotetext{
${ }_{119}$ Lando and Rose (n 93) 20-21.

${ }^{120}$ For a similar division see Mak, Performance-Oriented Remedies in European Sale of Goods Law (n 82) 64 -69; Ogus (n 54) 256-262.

121 Lon Fuller and William Perdue, 'The Reliance Interest in Contract Damages' (1936) Yale L. J. 52.

122 The expectations of the creditor are stronger in case of a consumer transaction. The House of Lords in Co-operative Insurance Society v Argyll Stores [1998] AC 1 stated that as the transaction is commercial, its purpose is to obtain money thus awarding damages would be an appropriate remedy. It flows from this that in case of consumer contracts, the purpose of the transaction is rather to satisfy the necessities of the consumer which are not always able to be expressed in an award of damages.

${ }^{123}$ Dori Kimel, From Promise to Contract: Towards a Liberal Theory of Contract (Hart Publishing 2004) 96, 114. Compare to the notion of State sovereignty in investment arbitration acting as a bar for orders of specific performance (e.g. - Art. 26 (8) of the Energy Charter Treaty (signed December 1994, entered into force April 1998, (1995) 34 ILM 360)).

${ }^{124}$ Farnsworth, Contract (n 27) 730.
} 
be analysed in terms of bilateral bargains rather than unilateral promises. ${ }^{125}$ In M. Schmidt-Kessel's words: 'freedom presupposes the possibility to bind oneself'. ${ }^{126}$ A person can waive in advance his rights and liberties, ${ }^{127}$ including through undertaking contractual obligations, subject to respect of the prohibition of self-enslavement. ${ }^{128}$ Moreover, the invocation of human rights of the debtor would be contrary to the principle of estoppel. In light of this, the argument that obligations created by voluntary undertaking can be performed only voluntarily is not tenable. ${ }^{129}$ Rather, justice and fairness oblige a party to keep his words. ${ }^{130}$

A perusal of the rules of positive law shows that courts strive to balance orders of specific performance with the freedom of debtor. In particular, in cases when the commitments are particularly personal, courts would reject a claim for an order of specific performance. Moreover, the argument of personal freedom works only for a limited category of cases (personal services) and does not cover other instances where specific performance could be requested. ${ }^{131}$

S. Shavell argues that breach of the contract is not immoral, as the contracts are often incomplete and parties may face situations that have not been foreseen at the moment of the conclusion of the contract. ${ }^{132}$ Despite the convincing logic of this argument, it needs to be stressed that, though contracts do not foresee everything, their incompleteness is filled in by legal default rules which are 'incorporated' into the text of the contract.

\footnotetext{
${ }^{125}$ James Penner, 'Voluntary Obligations and the Scope of the Law of Contract' (1996) 2 Legal Theory 325.

${ }^{126}$ Schmidt-Kessel (n 16) 71.

${ }^{127}$ The European Court of Human Rights answers affirmatively to the question whether a person can waive its liberty in advance. See Audley Sheppard, 'Interim ILA Report on Public Policy as a Bar to Enforcement of International Arbitral Awards' (2003) 19 Arb. Int'l 217, 233-234.

${ }^{128}$ Prince Saprai, 'The Principle against Self-Enslavement in Contract Law' (2009) 26 J. Contract L. 25

${ }^{129}$ S.A. Smith, 'Performance, Punishment, and the Nature of Contractual Obligation' (1997) 60 Modern Law Review 360.

${ }^{130}$ Peter Linzer, 'On the Amorality of Contract Remedies - Efficiency, Equity, and the Second Restatement' (1981) 81 Colum. L. Rev. 111, 138-139.

${ }^{131}$ Kimel, From Promise to Contract: Towards a Liberal Theory of Contract (n 123) 96-97; Smith (n 129) 364.

${ }^{132}$ Steven Shavell, 'Why Breach of Contract May not Be Immoral Given the Incompleteness of Contracts?' (2009) 107 Mich. L. Rev. 1569.
} 


\section{Economic Analysis of the Breach of Contract vs. Traditional Conception of the Breach}

The second dilemma opposes, on the one hand, the economic approach to the contract breach which advocates the efficient breach of the contract and, on the other hand, the traditional conception of the contract breach which invokes moral and legal arguments to support the general availability of specific performance. The economic approach of the efficient breach departs from the idea that the debtor should breach the contract each time that would lead to a Pareto improvement, i.e. - when the debtor is better off by breaching the contract and performing another transaction while the creditor to the initial contract is not worse off. ${ }^{133}$

This approach is, in principle, well-reasoned. The property, including the contractual claims, has an inherent social function ${ }^{134}$ and agglomeration of efficient breaches would accord with the public interest. Consequently, the private interest of a party needs to be sacrificed, all the more so that the debtor receives full compensation. Ordering specific performance is believed to preclude efficient breaches of contract, assuming that the contracting parties would not be able to renegotiate the contract and as a result the debtor would not be able to buy out his duty to perform. ${ }^{135}$ Hence, a 'liability rule ${ }^{136}$ imposing an award of damages is considered to be a more efficient remedy for breaches of contract, as it would permit to buy a legal way out of the contract. ${ }^{137}$

It is submitted that this theory is unworkable and defective. The theory of efficient breach has its roots in common law systems and the expansion of the theory from the U.S. law to civil law systems and even to England may face a considerable number of obstacles on the practical level (e.g. - disgorgement remedy aimed at surrendering the gain the

\footnotetext{
${ }^{133}$ Richard Posner, Economic Analysis of Law ( $7^{\text {th }}$ edn, Aspen Publishers 2007) 131.

${ }^{134}$ Rosalyn Higgins, The Taking of Property by the State: Recent Developments in International Law' 176 Recueil des cours 259 (The Hague 1983) 263.

${ }^{135}$ Ronald Scalise, "Why No "Efficient Breach" in the Civil Law?: A Comparative Assessment if the Doctrine of Efficient Breach of Contract' (2007) 55 Am. J. Comp. L. 721, 733-734.

${ }^{136}$ Guido Calabresi and Douglas Melamed, 'Property Rules, Liability Rules and Inalienability: One View of the Cathedral' (1982) 85 Harvard L. Rev. 1089.

${ }^{137}$ Barak Medina, 'Renegotiation, 'Efficient Breach' and Adjustement: The Choice of Remedy for Breach of Contract as a Choice of a Contract-Modification Theory', in Cohen and McKendrick (eds), Comparative Remedies for Breach of Contract (n 18) 52.
} 
debtor received from the 'efficient breach' to the creditor). ${ }^{138}$ For instance, English law permits creditors to recover the profits debtors have gained by breaching agreements. ${ }^{139}$ This would discourage the debtor to breach the contract if the additional sum he will receive from a thirdparty will need to be transferred to the creditor. Moreover, a U.S. court, applying English law (Rookes v Barnard [1964] A.C. 1129), awarded punitive damages for a contractual breach, as debtor's conduct has been calculated by him to make a profit which may well exceed the compensation payable to the plaintiff. ${ }^{140}$ Punitive damages would be a real deterrent for efficient breaches.

It is sometimes inaccurately argued that the exception of severe hardship available under different legal systems compared above is a reflection of the efficient breach theory. ${ }^{141}$ But that exception needs to be distinguished from the theory of efficient breach as the former sets out a higher threshold, and the opportunity costs do not seem to be part of the test under the severe hardship defence. ${ }^{142}$

The theory of efficient breach has provoked extensive debates in the academic circles. Apart from general objections to the economic analysis of law, ${ }^{143}$ the economic approach to the specific performance has been criticised on grounds of morality and sanctity of contracts. ${ }^{144}$ It is even doubtful that the theory of efficient breach accounts properly for real economic behaviour. The theory, being part of the neoclassical

${ }^{138}$ Qi Zhou, 'Is Seller's Efficient Breach Possible under English Sale Law?' (2008) 24 J. Contract L. 268.

${ }^{139}$ Attorney General v Blake [2001] 1 A.C. 268.

${ }^{140}$ Ronald Brand, 'Punitive Damages and the Recognition of Judgments' (1996) 43 Neth. Int'l L. Rev. 143, 169.

${ }^{141}$ Gerrit de Geest, 'Specific Performance, Damages and Unforeseen Contingencies in the Draft Common Frame of Reference', in Pierre Larouche and Filomena Chirico (eds), Economic Analysis of the DCFR (Sellier 2010) 126.

${ }^{142}$ Faust and Wiese (n 84) 58-59.

${ }^{143}$ Guido Calabresi, 'The Pointlessness of Pareto' (1991) 100 Yale L. J. 1211; Posner, Economic Analysis of Law (n 133) 26-27.

144 Jones and Goodhart, Specific Performance (n 19) 3-4; Mak, Performance-Oriented Remedies in European Sale of Goods Law (n 82) 68. It has been argued that efficient breach is illegal as it implies taking of property, namely contractual rights (Daniel Friedmann, 'The Efficient Breach Fallacy', (1989) 18 J. Leg. Stud. 1, 13), or taking of the creditor's patrimonial entitlement to performance (Lionel Smith, 'Understanding Specific Performance', in Cohen and McKendrick (eds), Comparative Remedies for Breach of Contract (n 18) 227). 
economical paradigm, assumes that efficiency of a breach would always prompt the debtor to breach the contract. By contrast, behavioural economics $^{145}$ questions the assumption of the neoclassical theory that economic actors are always rational. ${ }^{146}$ In the real world, the behaviour of economic actors is not always determined by self-interest but also by a whole range of physical and psychological constraints. ${ }^{147}$ Economic actors may not breach the contract when it would be efficient to do so due to the concerns of fairness, ${ }^{148}$ loyalty to the original creditor and lack of will power. As a result, introduction of the rule on efficient breach would not produce the predicted amount of efficiency in practice.

The lack of sufficient empirical evidence is sometimes invoked to repulse conclusions of the theory of efficient breach as to the alleged ineffectiveness of specific performance and, in particular, as to the prebreach and post-breach transaction costs generated by that remedy. ${ }^{149}$ Abstract discussions of transactions costs generated by an order of specific performance seem to be very speculative. In any case, it seems that the transactions costs facing two parties who are already in a contractual relationship are less than the costs of litigation. ${ }^{150}$

Followers of the theory of efficient breach contend that it would be more burdensome for the debtor to comply with the order of specific performance, rather than for the creditor to suffer from the contract being broken. ${ }^{151}$ Rather, the creditor needs to mitigate the damage caused by the breach of contract ${ }^{152}$ by means of obtaining substitute performance.

\footnotetext{
${ }^{145}$ See, e.g., Dan Ariely 'Papers' < http://web.mit.edu/ariely/www/MIT/papers.shtml $\geq$ accessed15 April 2012.

${ }^{146}$ See Russell Korobkin and Thomas Ulen, 'Law and Behavioral Science: Removing the Rationality Assumption from Law and Economics' (2000) 88 Calif. L. Rev. 1051.

${ }^{147}$ Francesco Parisi and Vernon Smith (eds.), The Law and Economics of Irrational Behavior (Stanford University Press 2005)

${ }^{148}$ Korobkin and Ulen (n 146) 1137-1138.

${ }^{149}$ Paul Mahoney, 'Contract Remedies: General' in The Encyclopedia of Law \& Economics $(2000)<$ http://encyclo.findlaw.com/4600book.pdf $>$ accessed 15 April $2012,127$.

${ }^{150}$ Thomas Ulen, 'The Efficiency of Specific Performance: Toward a Unified Theory of Contract Remedies' (1984) 83 Mich. L. Rev. 341, 344.

${ }^{151}$ Co-operative Insurance Society v Argyll Stores [1998] AC 115 . Similarly, it is argued that the creditor may have other motives to claim specific performance vengeance, desire to intimidate other debtors, etc. (Edward Yorio, 'In Defence of Monetary Damages for Breach of Contract' (1982) 82 Colum. L. Rev. 1365, 1373). ${ }^{152}$ Smith (n 144) 227.
} 
Others argue that the debtor would be subject to excessive burden only in case of obligations to produce goods, rather than deliver them, as the process of producing goods requires additional efforts and resources, whereas, in case of an obligation to give, the contribution of resources would not excessively burden the debtor. ${ }^{153}$

This objection to the specific performance can, nevertheless, be discounted. It obscures the fact that damages awarded to the creditor can in some cases be under-compensatory. ${ }^{154}$ Apart from frustration, vexation $^{155}$ and reputation in the market which do not in all probability appear in the calculation of damages, there is the issue of costs related to the judicial determination of damages ${ }^{156}$ and of the risk of error in the calculation of damages. ${ }^{157}$ Even when adequate damages are granted, there could be considerable costs incurred in searching for substitute goods or services. ${ }^{158}$ Moreover, the award of damages can be rendered under-compensatory by way of the operation of the principle of Hadley $v$ Baxendale $^{159}$ which limits the damages of the creditor to the foreseeable loss. ${ }^{160}$ The risk of under-compensation will in some cases force the creditor to incur costs to take additional precautions to cover the risk of the breach of contract. ${ }^{161}$ Furthermore, the creditor may encounter practical problems in enforcing the judgment for a monetary award (e.g. collecting the damages award, the instability of currency rates), ${ }^{162}$ though it remains true that similar enforcement problems may appear in the

${ }^{153}$ Steven Shavell, 'The Design of Contracts and Remedies for Breach' (1984) 99 Q. J. Econ. 121; Steven Shavell, 'Specific Performance Versus Damages For Breach Of Contract: An Economic Analysis' (2006) 84 Tex. L. Rev. 831; William Bishop, 'The Choice of Remedy for Breach of Contract' (1985) 14 J. Leg. Stud. 299, 301, 304.

${ }_{154}$ Alan Schwartz, 'The Case for Specific Performance' (1979) 89 Yale L.J. 271, 271.

${ }^{155}$ Farley v Skinner (No 2) [2001] 3 WLR 899 (HL).

${ }_{156}^{156}$ Walgreen v Sara Creek Property, 966 F. 2d 273 (7th Cir 1993) 277.

${ }^{157}$ Geerte Hesen, Robert Hardy, 'Dutch Contract Remedies from a Law and

Economics Perspective, in Smits, Haas and Hesen (eds), Specific Performance in Contract Law: National and Other Perspectives (n 84) 295-296.

${ }^{158}$ Kronman (n 54) 363-364.

${ }^{159}$ Hadley v Baxendale [1854] 156 ER 145.

${ }^{160}$ Melvin Eisenberg, 'Actual and Virtual Specific Performance, the Theory of Efficient Breach, and the Indifference Principle of Contract Law' (2005) 23 Cal. L. Rev. 9751049.

${ }^{161}$ Richard Craswell, 'Contract Remedies, Renegotiation, and the Theory of Efficient Breach' (1987-1988) 61 S. Cal. L. Rev. 629.

${ }^{162}$ Shael Herman, 'Specific Performance: A Comparative Analysis' (2003) 7 Edin. L. Rev. $194214-215$. 
course of enforcing an order for specific performance.

Turning to the requirement of mitigation of damages, it is argued that the 'duty' to mitigate does not impose any duties in the ordinary meaning of that word (rather, the creditor would be barred from requiring damages if he did not mitigate the loss) and the doctrine of mitigation should not act as a bar for the creditor to claim specific performance. ${ }^{163}$

The foregoing analysis leads to the conclusion that, in a (nonnegligible) number of cases, the efficient breach of the contract would not even be efficient according to the Kaldor-Hicks efficiency criterion, defined $^{164}$ as the situation when one party is better off and can transfer compensation to the other party to make it no worse off. This shows that the theory of efficient breach can be biased towards the debtor ${ }^{165}$ and can ignore the expectations of the creditor.

On closer analysis, the remedy of specific performance is economically efficient. Providing the courts with the power to grant orders of specific performance will shift the burden of quantifying the damage and avoiding any excessive burden on the debtor to the parties who are able to substitute the specific performance order by their postdispute settlement. ${ }^{166}$ That being the case, the debtor would be able to buy out his duty to perform the contract, thus permitting efficient breaches at the end of the day. Leaving the function of quantifying the damage to the parties would also have a distributional effect, partially allocating the price that was proposed by a third-party to the original creditor. ${ }^{167}$ The price renegotiated between the debtor and creditor would take into account the sum the new buyer is ready to pay to the debtor, whereas the damages award would have ignored that factor.

\footnotetext{
${ }^{163}$ Kimel, From Promise to Contract: Towards a Liberal Theory of Contract (n 123) 109-112.

${ }^{164}$ Mitchell Polinshky and Steven Shavell (eds), Handbook of Law and Economics (Amsterdam, 2007) Vol. II 505.

165 Only in exceptional cases, when the creditor is under the risk of leaving the business (Sky Petroleum Ltd. v V.I.P. Petroleum Ltd. [1974] 1 W.L.R. 576), the use of the theory of efficient would be legitimate. Compare to the U.S. case-law that grants specific performance to protect the plan of 'doing business' (Victor Goldberg, Framing Contract Law: An Economic Perspective (Harvard University Press 2006) 213).

${ }^{166}$ Walgreen $v$ Sara Creek Property, 966 F. 2d 273 (7th Cir 1993) 275-276; Kronman (n 55) 353.

${ }^{167}$ Ogus (n 54) 259-260.
} 
However, it is correctly ascertained that costs of renegotiation incurred to renegotiate the order of specific performance should not be overlooked. ${ }^{168}$ When the costs are so high that no agreement would be reached between the parties, the court must intervene to award money damages. ${ }^{169}$ Furthermore, in some markets the third-party would be able to locate the initial creditor of the contract and negotiate with him the option of buying out the specific performance ${ }^{170}$ by way of contractual assignment. However, risk-averse third parties may be reluctant to proceed in this way as the assignment carries an element of risk associated with the potential intervention of third parties (e.g. - creditors of the assignor).

The analysis hitherto suggests that, when the transaction costs are not prohibitive, neither of the remedies is efficient per se, as both the damages rule and specific performance permit an efficient breach of the contract. ${ }^{171}$ The real effectiveness of a remedy can be measured only by comparing transaction costs incurred by the parties when negotiating the possibility to buy out the right to specific performance. ${ }^{172}$

It has been suggested from an ex ante perspective that the probability of getting what is contracted via the order of specific performance can act as an incentive for the parties to continue contracting in future. ${ }^{173}$ The parties would feel more confident that no policy considerations of courts would stand in their way of getting what they expected to receive. To this one could object that the possibility of a breach of contract and of a dispute arising at the stage of performance of the contract would not be considered to be realistic in the course of negotiating the contract. It is notable that the Australian Government has recently announced that it would not include any dispute settlement provisions into the Bilateral Investment Treaties signed on its part. This

\footnotetext{
${ }^{168}$ Kronman (n 55).

${ }^{169}$ Ulen (n 150) 401-402.

${ }^{170}$ Lewis Kornhauser, 'An Introduction to the Economic Analysis of Contract

Remedies' (1986) 57 U. Colo. L. Rev. 683, 715.

${ }^{171}$ Ian Ayres and Eric Talley, 'Solomonic Bargaining: Dividing a Legal Entitlement

to Facilitate Coasean Trade' (1995) 104 Yale L. J. 1027, 1098-1099.

${ }^{172}$ Ian Macneil, 'Efficient Breach of Contract: Circles in the Sky' (1982) 68 Virg. L. Rev. 947.

${ }^{173}$ Friedmann (n 18) 7; Jones and Goodhart, Specific Performance (n 19) 4; Kimel, From Promise to Contract: Towards a Liberal Theory of Contract (n 123) 107-108.
} 
decision was supported by the economic analysis to the effect that dispute settlement provisions do not in reality affect the decision taken by investors to invest in Australia. ${ }^{174}$

These objections notwithstanding, it seems likely that the availability of specific performance may influence the desire to contract when the parties are able to choose the applicable law. The availability of specific performance would not impact the decision to contract when the interested parties do not have any alternative. However, provided the parties can change the regime with minimal costs, they will opt for the general availability of specific performance. ${ }^{175}$

Finally, it has been shown above that the EU optional instrument on contractual obligations is intended to be applicable within the context of arbitration. However, arbitrators do not share the concerns and objectives of the judiciary. ${ }^{176}$ Efficiency concerns are absolutely valid for state organs such as courts. By contrast, an arbitral tribunal is constituted for the single purpose of litigating the dispute between (generally) two commercial parties. One might question whether a party-constituted tribunal needs to worry about the impact of a remedy upon wider society?

\section{Legal Certainty}

The analysis thus far suggests that there are no insurmountable theoretical objections to the remedy of specific performance. It is submitted in this chapter that the requirement of legal certainty militates in favour of the general availability of specific performance in the European Union. It is a truism that legal certainty, understood as previsibility of the judicial decision to parties to a dispute, is of paramount importance for contracting parties, especially risk-averse contractors.

The need for legal certainty is self-evident in the contractual domain, as the parties committing themselves to obligations need to be able to foresee the fate of such obligations. Certainty about the fate of commitments undertaken by parties would arguably foster the conclusion of contracts.

\footnotetext{
${ }^{174}$ The Productivity Commission 'Some specific provisions in BRTAs', $<$ http://www.pc.gov.au/data/assets/pdf_file/0009/104220/17-chapter14.pdf $>$ accessed15 April 2012, 256.

${ }^{175}$ For a discussion see Part D below.

${ }^{176}$ Schneider (n 102) 4-5.
} 
It is likely that the certainty concerns are particularly vigorous within the framework of an internal European common market. It is argued that the process of European integration leads to an increase of legal certainty and minimisation of judicial discretion. The expansion of the European Union law has the effect of shrinking such discretion. This happened in regard to the doctrine of forum non conveniens and to the 'proper law of contract' analysis, both abandonned in favour of Brussels $\mathrm{I}^{177}$ and Rome I Regulations respectively. Thus, the European Court of Justice in Owusu $v$ Jackson has invalidated the use of the doctrine of forum non conveniens by which English courts retained high degree of discretion as being inter alia contrary to the legal certainty. ${ }^{178}$ A similar metamorphose has undergone the approach of English courts with regard to the choice-of-forum agreements. ${ }^{179}$ English courts lost the wide discretion they had enjoyed under all mentioned doctrines.

It is submitted that the wave of certainty will reach the remedy of specific performance too. Remedy of specific performance in the DCFR is based on the premise of legal certainty. ${ }^{180}$ Despite the fact the DCFR is using such vague concepts as 'good faith', 'reasonableness', 'excessive', etc., it provides quite certain solutions for the issue of remedies. Existence of flexible rules directing the process of ordering specific performance is not incompatible with the certainty in remedies ${ }^{181}$ and does not qualify as judicial discretion. ${ }^{182}$

The situation is different under English law. English law has always underlined the fact that judges granting the order for specific performance, a type of equitable remedy, have discretionary power to do

\footnotetext{
${ }^{177}$ Council Regulation (EC) No 44/2001 of 22 December 2000 on jurisdiction and the recognition and enforcement of judgments in civil and commercial matters (OJ L 12, 16.1.2001).

${ }^{178}$ Owusu v Jackson C-281/02 [2005] ECR I-1383, [38].

${ }^{179}$ Owners of Cargo Lately Laden on Board the Eleftheria v Owners of the Eleftheria [1969] 2 W.L.R. 1073; Owners of Cargo Lately Laden on Board the Fehmarn v Owners of the Fehmarn (The Fehmarn) [1957] 2 Lloyd's Rep. 551.

${ }^{180}$ von Bar and Clive, Principles, Definitions and Model Rules of European Private Law, Draft Common Frame of Reference (DCFR) (n 7) 830.

${ }^{181}$ Friedmann (n 18) 16-17.

${ }^{182}$ Lando and Beale, Principles of European Contract Law: Parts I and II (n 14) 396.
} 
so. ${ }^{183}$ With respect to Lord Hoffman's declaration that there are 'wellestablished principles which govern the exercise of the discretion', ${ }^{184}$ it has to be noted that the Court of Appeal correctly stated in Warren $v$ Mendy that granting a discretionary remedy such as an order for specific performance:

depends on the infinitely variable facts of the individual case. Although statements of the principles on which the discretion ought to be exercised in some particular area are often authoritative, they are principles of practice rather than of law, whose application may be rendered inappropriate by the finest of factual variations between one case and another. ${ }^{185}$

It would be inconceivable to import a common-law type of judicial discretion in a codified, civil-law-type instrument such as the DCFR. Judges in the countries of civil law are more used to applying straightforward provisions of civil codes, rather than utilising a high degree of discretion.

It by no means follows, however, that granting discretion to judges is worse than the more straightforward and mechanical approach of civil law countries. Nevertheless, the rule on specific performance must be seen within the context of European integration and creation of internal market. The desire to create a common market requires to adjust the judicial process to the necessities of European common market and to sacrifice some national law particularities. Legal certainty will certainly contribute to the promotion of internal market, which is one of the principles of European Union and also underlies the DCFR project. ${ }^{186}$

The reasoning above suggests that the territorial scope of application of the DCFR shall be limited to the territory of the European Union territory, ${ }^{187}$ considering that the English traditional approach is only

\footnotetext{
${ }^{183}$ Co-operative Insurance Society v Argyll Stores [1998] AC 1 (HL) 9, where Lord Hoffmann stated: 'A decree of specific performance is of course a discretionary remedy...'.

${ }^{184}$ ibid 11, 16. See also Burrows, Remedies for Torts and Breach of Contract (n 40) 457.

${ }^{185}$ Warren v Mendy [1989] 1 WLR 853, 860.

186 von Bar and Clive, Principles, Definitions and Model Rules of European Private Law, Draft Common Frame of Reference (DCFR) (n 7) 23.

${ }^{187}$ Compare to the territorial limitation of remedies of specific performance under English law (see Part B.2 above).
} 
abandoned for the sake of providing legal certainty within the European legal space. In other cases, the traditional English approach shall be left untouched. For this reason, the desire of the European commission to extend the DCFR to domestic issues ${ }^{188}$ should be doubted.

It should be observed that non-discretionary specific performance is already adopted on the EU sector-specific level. Directive 1999/44/EC of the European Parliament and of the Council of 25 May 1999 on certain aspects of the sale of consumer goods and associated guarantees vests the creditor with the right to require repair and replacement of goods (Art. 3(3)). ${ }^{189}$ Nonetheless, the question of whether the latter Directive trumps the reluctance of English law to afford specific performance and the desire to keep discretionary powers is still moot, ${ }^{190}$ and a review of the general English approach towards specific performance is advised. ${ }^{191}$

\section{E. CONCLUSION}

The analysis offered in this dissertation favours the general availability of specific performance. Legal systems vary in their approaches to the availability of the said remedy. As a result, one of the approaches needs to be preferred, if the route of Europeanisation is undertaken. Having shown that the theoretical objections to the specific performance can be overcome, it was stressed that the remedy of specific performance fosters legal certainty which is a necessary prerequisite for the construction of an internal common market. A quotation from the House of Lords neatly concludes the point:

Although the list [of divergences from English law] contains topics of fundamental importance, it is important to remember that the DCFR represents

\footnotetext{
${ }^{188}$ Green Paper from the Commission on Policy Options for Progress towards a European Contract Law for Consumers and Businesses (n 3) 12.

${ }^{189}$ Aneta Wiewiorowska-Domagalska, 'Certain Aspects of the Right of Repair and Replacement under EC Directive 1999/44 and its Implementation in Poland', in Smits, Haas and Hesen (eds), Specific Performance in Contract Law: National and Other Perspectives (n 84) 133.

${ }^{190}$ Some commentators consider that this rule would prevail over the discretionary analysis of English law. See D.R. Harris, 'Specific Performance - a Regular Remedy for Consumers?' (2003) 119 LQR 541, 543.

${ }^{191}$ Vanessa Mak, 'Specific Performance in English Consumer Law', in Smits, Haas and Hesen (eds), Specific Performance in Contract Law: National and Other Perspectives (n 84) 122-125.
} 
a compromise between lawyers coming from different legal systems. It is not only English law that would have to undergo changes if the CFR were to be adopted as a legally binding instrument. Other legal systems would have to adapt as well. ${ }^{192}$

${ }^{192}$ House of Lords, European Contract Law: The Draft Common Frame of Reference (n 6) 4. 